\title{
EDITORIAL
}

\section{A PRICE TOO HIGH: RETHINKING NUCLEAR WEAPONS IN LIGHT OF THEIR HUMAN COST}

\section{Vincent Bernard, Editor-in-Chief*}

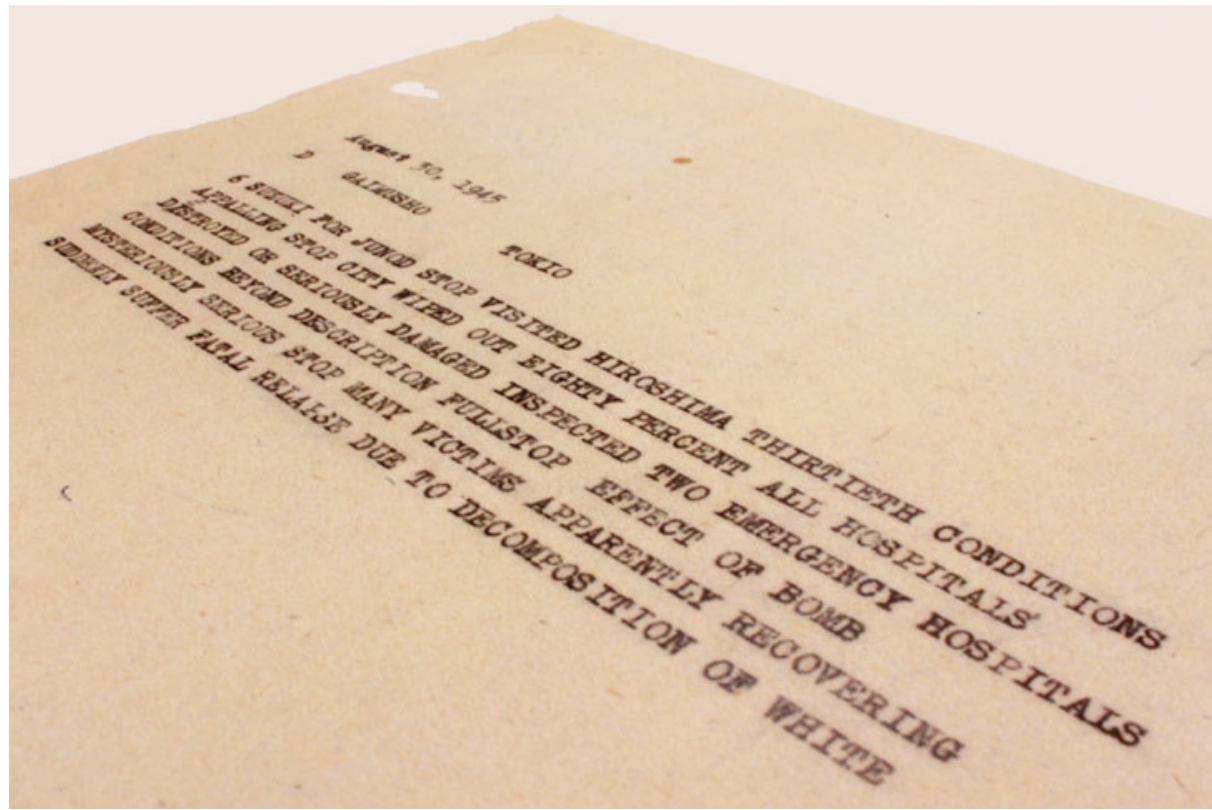

Visited Hiroshima thirtieth, conditions appalling stop city wiped out, eighty percent all hospitals destroyed or seriously damaged; inspected two emergency hospitals, conditions beyond description full stop effect of bomb mysteriously serious stop many victims, apparently recovering, suddenly suffer fatal relapse due to decomposition of white blood cells and other internal injuries, now dying in great numbers stop estimated still over one hundred thousand wounded in emergency hospitals located surroundings, sadly lacking bandaging materials, medicines stop.

Fritz Bilfinger, ICRC, telegram dated 30 August $1945^{1}$

* The author would like to thank Ellen Policinski, thematic editor for the Review, for her contribution to this issue. 
It is estimated that approximately 340,000 people died immediately and within the five years following the bombs being dropped on Hiroshima and Nagasaki on 6 and 9 August $1945 .^{2}$ From the day of the bombing to today, the International Red Cross and Red Crescent Movement (the Movement) has been responding to the needs of victims and has been consistent in its opposition to the use of nuclear weapons.

\section{The Red Cross and Red Crescent: A consistent engagement on behalf of victims}

The day after the first atomic bomb was dropped on Hiroshima, several medical teams from the Japanese Red Cross Society arrived in Hiroshima from neighbouring towns. They helped the staff at the Japanese Red Cross hospital, which while badly damaged was still operating, and served in improvised dispensaries set up in tents in different parts of the devastated city.

The first foreign Red Cross worker on the ground in Hiroshima was Fritz Bilfinger from the International Committee of the Red Cross (ICRC). He was able to reach Hiroshima on 29 August and sent the telegram above back to the ICRC office in Tokyo. A few days later, Marcel Junod arrived in Hiroshima from ICRC Tokyo and described a city where "there was nothing but silence and desolation". According to witnesses encountered by Junod, within a few seconds of the blast,

thousands of human beings in the streets and gardens in the town centre, struck by a wave of intense heat, died like flies. Others lay writhing like worms, atrociously burned. All private houses, warehouses, etc., disappeared as if swept away by a supernatural power. Trams were picked up and hurled yards away, as if they were weightless; trains were flung off the rails .... Every living thing was petrified in an attitude of acute pain. ${ }^{4}$

Makeshift hospitals were overcrowded with people suffering from severe injuries due to burns and radiation. There was a general lack of equipment and medicines, and also of medical staff, who had been decimated. The few doctors and nurses left were facing totally new types of wounds, for which there was no effective treatment. ${ }^{5}$

1 Fritz Bilfinger, telegram dated 30 August 1945, ICRC Archives, File No. G. 8/76. A copy of the original telegram - as well as Bilfinger's report on the effects of the atomic bomb at Hiroshima, and photos - is available on the ICRC website at: http://icrchistory.tumblr.com/post/125827746385/rapport-de-fritzbilfinger-délégué-du-cicr-au (all online references were accessed in November 2015). Bilfinger's full report, including a copy of the telegram in its entirety, can be found in the "Reports and Documents" section of this issue of the Review.

2 See ICRC special web pages for the anniversary of the bombings, "Hiroshima and Nagasaki: 70 Years On, Survivors and Their Families Still Gravely Affected", available at: www.icrc.org/en/hiroshima-nagasaki.

3 François Bugnion, "Remembering Hiroshima", International Review of the Red Cross, Vol. 77, No. 813, 1995, available at: www.icrc.org/eng/resources/documents/misc/57jmge.htm.

4 Marcel Junod, “The Hiroshima Disaster - a Doctor's Account”, 12 September 2005, available at: www. icrc.org/eng/resources/documents/misc/hiroshima-junod-120905.htm.

5 See Marcel Junod, "The Hiroshima Disaster", International Review of the Red Cross, Vol. 64, No. 737, 1982; Marcel Junod, "The Hiroshima Disaster (Continued)", International Review of the Red Cross, Vol. 64, No. 738, 1982. For an account of the work of the ICRC right after the Hiroshima bombing and in the following decades, see F. Bugnion, above note 3, pp. 307-313. 
Still today, the Japanese Red Cross hospitals continue to treat several thousand victims for cancers and illnesses attributable to the 1945 atomic bombings of those cities. In the period between April 2014 and March 2015, 4,657 officially recognized atomic bomb survivors were treated at the Hiroshima Atomic-Bomb Survivors Hospital, and 7,297 officially recognized atomic bomb survivors were treated by the Japanese Red Cross Nagasaki Genbaku Hospital. ${ }^{6}$ The survivors are among the strongest voices calling our attention to the severity and enormous scale of the suffering caused by nuclear weapons. ${ }^{7}$

The ICRC took a clear stance on nuclear weapons soon after such weapons were used for the first time. Less than a month after the first atomic bomb had been dropped on Hiroshima, the ICRC sent a message to National Societies stating that nuclear weapons should be abolished. ${ }^{8}$ The position of the ICRC was later summarized in the following manner:

Precluding any discrimination between military objectives and civilian objects, causing atrocious suffering to those stricken by its effects, and impeding any possibility of bringing aid to the victims of the cataclysm they cause, nuclear weapons called into question the very foundations of the law of war and of the assistance activities conducted by the Red Cross. ${ }^{9}$

Seventy years after the bombings of Hiroshima and Nagasaki, the international community still finds it difficult to make real progress towards the prohibition and elimination of nuclear weapons. Nevertheless, the International Red Cross and Red Crescent Movement has a deep responsibility to "rise in defence of humanity" 10 and to provide a voice to draw attention to the unacceptable humanitarian consequences of the use of nuclear weapons, highlight the implications of such weapons under international humanitarian law and urge

6 ICRC and Japanese Red Cross Society, "Long-Term Health Consequences of Nuclear Weapons: 70 Years On, Red Cross Hospitals Still Treat Thousands of Atomic Bomb Survivors", Information Note No. 5, July 2015.

7 See the hibakusha testimony in the "Voices and Perspectives" section of this issue of the Review.

8 Ibid.; "The End of Hostilities and the Future Tasks of the Red Cross", Circular Letter No. 370 to the Central Committees of the Red Cross Societies, 5 September 1945, in Report of the International Committee of the Red Cross on Its Activities during the Second World War, Vol. 1, ICRC, Geneva, May 1948, pp. 688-690. Since then, the ICRC's position has been consistent: see, for instance, Jakob Kellenberger and Peter Maurer's speeches reproduced in this issue of the Review. See also Statement of the ICRC at the UN General Assembly, 51st Session, 19 October 1996, available at: www.icrc.org/eng/ resources/documents/misc/57jncx.htm; Council of Delegates of the International Red Cross and Red Crescent Movement, Resolution 1, "Working Towards the Elimination of Nuclear Weapons", 26 November 2011, available at: www.icrc.org/eng/resources/documents/resolution/council-delegatesresolution-1-2011.htm; Council of Delegates of the International Red Cross and Red Crescent Movement, Resolution 1, "Working Towards the Elimination of Nuclear Weapons: Four-Year Action Plan", 17-18 November 2013, available at: www.icrc.org/eng/resources/documents/publication/p1140. htm.

9 Francois Bugnion, "The International Committee of the Red Cross and Nuclear Weapons: From Hiroshima to the Dawn of the 21st Century", International Review of the Red Cross, Vol. 87, No. 859, 2005, p. 512, available at: www.icrc.org/eng/resources/documents/article/review/review-859-p511.htm.

10 Ibid. 
governments to pursue the prohibition and elimination of these weapons as quickly as possible. In line with the ICRC's consistent position on nuclear weapons, but also in view of the recent initiative to reframe the issue of nuclear weapons in terms of the humanitarian consequences of their use, the Review decided to publish an issue on nuclear weapons.

\section{Still the most serious threat to humanity}

Since their first use in 1945, the world has known about the catastrophic effects of nuclear weapons. The danger of nuclear attacks was ever-present for more than four decades during the Cold War. In some countries, preparedness drills were regularly conducted, nuclear shelters were maintained in anticipation of a potential nuclear attack, and anti-nuclear protests took place. Today, the level of awareness is much different. Many people, including most of those born after the end of the Cold War, are unaware of the continued risks that nuclear weapons pose to humanity and the severe humanitarian consequences that would follow should such weapons ever be used.

While the threat no longer seems as present, paradoxically we now know more than ever before about the effects of even limited nuclear war on the environment and health of human beings, ${ }^{11}$ and that, as was highlighted by the International Court of Justice (ICJ) in its 1996 its Advisory Opinion on the Legality of the Threat or Use of Nuclear Weapons (Nuclear Weapons Advisory Opinion), " $[\mathrm{t}]$ he destructive power of nuclear weapons cannot be contained in either space or time". ${ }^{12}$

Although nuclear weapons have not been used in armed conflict since 1945, nuclear testing has had terrible consequences on the lives of populations living nearby and some of the military personnel involved. These include the inhabitants of testing areas, often ethnic minorities or insular populations. Many testing areas have also suffered serious environmental damage. ${ }^{13}$

Despite these facts, nuclear weapons remain a pillar in the security policies of a number of States, and for some, possessing them has become a perverse status symbol. While the total number of nuclear weapons in the arsenals of the nucleararmed States is less than it was at the height of the Cold War, nuclear weapons States continue to maintain and even modernize their nuclear arsenals. Today, nearly 16,000 nuclear weapons are stored at sites located in fourteen countries, many

11 See, e.g., Ira Helfand, Nuclear Famine: Two Billion People At Risk? Global Impacts of Limited Nuclear War on Agriculture, Food Supplies and Human Nutrition, 2nd ed., International Physicians for the Prevention of Nuclear War and Physicians for Social Responsibility, November 2013, available at: www.ippnw.org/ nuclear-famine.html.

12 ICJ, Legality of the Threat or Use of Nuclear Weapons, Advisory Opinion, 8 July 1996, ICJ Reports 1996 (Nuclear Weapons Advisory Opinion), para. 35.

13 For an account of nuclear testing in the Pacific region in particular, including the effects on populations and the environment, see the article by Tilman Ruff in this issue of the Review. 
ready for immediate use. ${ }^{14}$ Approximately 1,800 nuclear warheads are kept on high alert status in the United States and Russia, ready to be fired in minutes. ${ }^{15}$ The vast majority of these weapons are much more powerful than the ones used in Hiroshima and Nagasaki. This makes the danger of their intentional or accidental detonation even more frightening.

Due to the fact that there has not been a nuclear attack since Nagasaki, the sense of urgency amongst the general public has faded. However, humanity may not be able to avoid accidental or intentional nuclear detonation forever. The fact that such weapons have not been used in more than seventy years is no guarantee that they will not be used again. The longer these weapons exist, and as they are developed by more States and possibly even acquired by non-State actors, the likelihood of another nuclear detonation increases.

\section{Not outside the scope of the law}

Contrary to some other weapons about which there is a serious concern in humanitarian terms, ${ }^{16}$ international humanitarian law (IHL) does not explicitly prohibit the use of nuclear weapons. This does not mean that the law is silent: IHL contains a range of general rules governing the conduct of hostilities that are relevant to assessing the legality of nuclear weapons, such as the rules on distinction and proportionality, the prohibition on indiscriminate attacks, the prohibition on the use of weapons of a nature to cause superfluous injury or unnecessary suffering, and the rules protecting the natural environment. At the core of these rules lies the general principle that individual civilians and the wider civilian population enjoy a general protection from the dangers arising from military operations.

It should not be forgotten that, in addition to destroying important military objectives, nuclear weapons were also meant to be used against urban areas and their civilian populations. The bombings of Hiroshima and Nagasaki were the culmination of an escalating series of bombing raids on major urban centres during the Spanish Civil War and the Second World War. Although there has been much debate about the legality of the Hiroshima and Nagasaki bombings under the rules applicable at the time, if carried out today such attacks would raise a range of serious issues and concern under current IHL rules.

In 1996, the ICJ issued its Nuclear Weapons Advisory Opinion, deciding that the use of nuclear weapons would "generally be contrary to the rules of

14 Ibid. See also Hans Kristensen and Robert Norris, "Worldwide Deployments of Nuclear Weapons, 2014", Bulletin of the Atomic Scientists, 28 August 2014, available at: http://bos.sagepub.com/content/early/2014/ 08/26/0096340214547619.full.

15 Hans Kristensen and Matthew McKinzie, "De-alerting Nuclear Forces", Bulletin of the Atomic Scientists, 19 June 2013, available at: http://thebulletin.org/de-alerting-nuclear-forces. See also the article by Hans Kristensen and Matthew McKinzie in this issue of the Review.

16 For example, chemical and biological weapons, anti-personnel landmines, cluster munitions, and blinding laser weapons. 
international law applicable in armed conflict, and in particular the principles and rules of humanitarian law". Despite this, it did not take a decision on whether such weapons would be compatible with the law in "an extreme circumstance of selfdefense in which the very survival of a State would be at stake", ${ }^{17}$ a part of the decision that has been widely criticized. ${ }^{18}$ At that time, the Review produced an issue addressing the topic of nuclear weapons, largely through the lens of the Nuclear Weapons Advisory Opinion. ${ }^{19}$ Since then, the Review has continued to publish regularly on the subject. ${ }^{20}$ Today, given the opportunity to capitalize on the increased focus on the humanitarian consequences of the use of nuclear weapons, it seems opportune to revisit the topic more fully in this thematic issue.

Nearly twenty years after the Nuclear Weapons Advisory Opinion, it is clear that nuclear weapons continue to raise serious concerns in humanitarian terms and that their use would raise serious questions about their compatibility with existing IHL rules. As the ICRC stated in 1996 in response to the Advisory Opinion, it is "difficult to envisage how a use of nuclear weapons could be compatible with the rules of international humanitarian law". ${ }^{21}$ In this edition, Louis Maresca and Eleanor Mitchell have concluded that the use of nuclear weapons in a populated area would amount to an indiscriminate attack, and in addition, that any use outside such areas should be presumed to be in violation of international law. ${ }^{22}$

\section{Reframing the issue: The humanitarian track}

Until recently, the discourse about nuclear weapons has primarily focused on deterrence, self-defence and the role of nuclear weapons in military doctrine more generally. Etymologically, the word "deterrence" is related to "terror", the fear inspired in a potential adversary by the threat of nuclear retaliation to an attack. According to this theory, one State's possession of nuclear weapons will deter others from using similar weapons out of the fear of reprisals.

17 Nuclear Weapons Advisory Opinion, above note 12.

18 See, e.g., Hisakazu Fujita, "The Advisory Opinion of the International Court of Justice on the Legality of Nuclear Weapons", International Review of the Red Cross, Vol. 79, No. 823, 1997; Daniel Thurer, "The Legality of the Threat or Use of Nuclear Weapons: The ICJ Advisory Opinion Reconsidered", in Volkerrecht und die Dynamik der Menschenrechte: Liber Amicorum Wolfram Karl, Wien, 2012.

19 Thematic issue on "Nuclear Weapons", International Review of the Red Cross, Vol. 79, No. 823, 1997, available at: www.icrc.org/eng/resources/international-review/review-316-nuclear-weapons/index.jsp.

20 Including Nobuko Margaret Kosuge, "Prompt and Utter Destruction: The Nagasaki Disaster and the Initial Medical Relief", International Review of the Red Cross, Vol. 89, No. 866, 2007, available at: www.icrc.org/eng/resources/documents/article/review/review-866-p279.htm; Thomas Fisher, "The ICRC and the 1962 Cuban Missile Crisis", International Review of the Red Cross, Vol. 83, No. 842, 2001, available at: www.icrc.org/eng/resources/documents/article/other/57jr5k.htm.

21 Statement of the ICRC to the United Nations General Assembly, 51st Session, 18 October 1996, as published in the International Review of the Red Cross, Vol. 78, No. 822, 1996, available at: www.icrc. org/eng/resources/documents/misc/57jncx.htm.

22 See the article by Lou Maresca and Eleanor Mitchell in this issue of the Review. 
As a witness to the devastation of 1945 , the role of the Movement is not to assess the political motivations behind the possession of certain weapons but to bring to the fore their humanitarian consequences and their implications under IHL principles and rules. In recent years, two notable ICRC initiatives have contributed to a renewed debate on nuclear weapons through the lens of their human cost.

First, assessments undertaken by the ICRC in 2007 and 2009 showed clearly that there is a lack of capacity at the national and international levels to effectively assist the victims of a nuclear detonation. "The evident lack of an international capacity to help such victims underscores the inescapable fact that to prevent the use of nuclear, radiological, biological and chemical weapons is an absolute imperative", concluded Dominique Loye and Robin Coupland. ${ }^{23}$

Second, ICRC President Jakob Kellenberger asserted in a seminal statement in 2010 that the organization

firmly believes that the debate about nuclear weapons must be conducted not only on the basis of military doctrines and power politics. ... The currency of this debate must ultimately be about human beings, about the fundamental rules of international humanitarian law, and about the collective future of humanity. ${ }^{24}$

Within the Movement, this was followed by a resolution reiterating its historic positions regarding nuclear weapons and encouraging States to work towards their elimination, together with a four-year action plan to that end. ${ }^{25}$

These developments, coupled with the final declaration of the 2010 Review Conference of the Treaty on the Non-Proliferation of Nuclear Weapons (NonProliferation Treaty, NPT), where NPT States Parties for the first time expressed their "deep concern at the catastrophic humanitarian consequences of any use of nuclear weapons", led to the humanitarian impact of nuclear weapons becoming the principal theme of the nuclear weapons debate. Three conferences on the humanitarian impact of nuclear weapons, in Oslo (2013), Nayarit (2014) and Vienna (2015), followed; these were the first multilateral meetings exclusively dedicated to the humanitarian aspects of the issue. The messages from these meetings went on to influence the discussions and positions of many States at the 2015 NPT Review Conference and the subsequent meetings of the United Nations (UN) General Assembly. The process culminated in a "Humanitarian Pledge" calling on States and other stakeholders to work to stigmatize, prohibit

23 Robin Coupland and Dominique Loye, "Who Will Assist the Victims of Use of Nuclear, Radiological, Biological or Chemical weapons - and How?", International Review of the Red Cross, Vol. 89, No. 866, 2007, p. 344. See also Robin Coupland and Dominique Loye, "International Assistance for Victims of Use of Nuclear, Radiological, Biological or Chemical Weapons: Time for a Reality Check?", International Review of the Red Cross, Vol. 91, No. 874, 2009. For an update on the ICRC's response framework, see the article by Gregor Malich, Robin Coupland, Steve Donnelly and Johnny Nehme in this issue of the Review.

24 Jakob Kellenberger, "Bringing the Era of Nuclear Weapons to an End", statement to the Geneva Diplomatic Corps, Geneva, 20 April 2010, reproduced in this issue of the Review.

25 Council of Delegates, Resolution 1 and Four-Year Action Plan, above note 8. 
and eliminate nuclear weapons, adopted by the UN General Assembly as Resolution 70/48. Some 139 States voted in favour of the resolution. ${ }^{26}$ In a 2015 speech to the diplomatic community in Geneva, ICRC President Peter Maurer drew attention to the sometimes overlooked element of the risk of accidental or unintentional nuclear detonation, ${ }^{27}$ further emphasizing the need to eliminate these weapons.

In light of what we know about the terrible consequences of the use of nuclear weapons, it is now more clear than ever that the international community must imperatively find a way to achieve total nuclear disarmament, through a ban treaty or otherwise. ${ }^{28}$ As long as nuclear weapons exist, there remains a risk that they might be detonated, and this must never happen again.

In order to prepare this thematic issue, the Review met with several hibakusha, survivors of the atomic bomb blasts in Hiroshima and Nagasaki. It interviewed the director of the Nagasaki Red Cross hospital and met the director of the Nagasaki Atomic Bomb Museum and the editors of the Chugoku Shimbun, a Hiroshima newspaper which runs an education campaign about the atomic bomb. The Review interviewed ICRC President Peter Maurer and Tadateru Konoe, president of the International Federation of Red Cross and Red Crescent Societies and of the Japanese Red Cross in Tokyo, immediately after their visit to Hiroshima and Nagasaki. The Review also met various journalists, writers, lawyers, humanitarian practitioners and experts at the conference on the humanitarian impact of nuclear weapons in Oslo in 2013. This work is reflected in the following pages.

The Review would like to express its gratitude to the contributors and pay tribute to the perseverance of the hibakusha, who continue to testify about their personal story and the loss of their family members and friends. The bombings of Hiroshima and Nagasaki are not only their personal tragedy, nor are they merely a page of Second World War history - nuclear weapons remain today a sword of Damocles hanging over humankind. Eliminate Nuclear Weapons", available at: www.icanw.org/pledge/; UNGA Res. 70/48, 11 December 2015, available at: www.icanw.org/wp-content/uploads/2015/03/N1541140.pdf.

27 See the February 2015 speech by Peter Maurer reproduced in this issue of the Review.

28 See the article by Treasa Dunworth in this issue of the Review. 